УДК 342.6

\author{
B. O. БоняK
}

\title{
МЕТОДОЛОГІЯ ДОСЛІДЖЕННЯ ОРГАНІЗАЦІЇ ТА ФУНКЦІОНУВАННЯ ОРГАНІВ ОХОРОНИ ПРАВОПОРЯДКУ УКРАЇНИ
}

Успіх проведення будь-якого наукового дослідження значною мірою залежить від методологічного інструментарію, який використовує вчений. Таким інструментарієм $i \in$ методологія.

Як у юриспруденшіi загалом, так і в науці конститушійного права зокрема методологія являє собою одну з наріжних та вкрай необхідних і складних пробллем, а їі вирішення має вихід на різні сторони правових досліджень, правотворчості та правореалізації [1, с. 33]. Визначення інструментарію, за допомогою якого буде здійснюватися дослідження організації й функціонування органів охорони правопорядку, $є$ надзвичайно важливим питанням, що має прикладний характер і вимагає належного теоретичного обгрунтування. Його успішне вирішення дасть змогу сформувати цілісну, внутрішньо узгоджену конституційно-правову модель системи органів охорони правопорядку України, яка може бути покладена в основу здійснення іï комплексного реформування. Вирішення зазначеної проблеми потребує відповідної методологічної бази, за допомогою якої будуть розв'язані визначені автором дослідницькі завдання.

Питання методології державно-правових досліджень розроблялися як вітчизняними, так і зарубіжними вченими, до яких можна зарахувати С.Д. Гусарєва, Радомира Д. Лукича, М.С. Кельмана, Д.А. Керімова, B.K. Колпакова, О.В. Петришина, П.М. Рабіновича, С.Г. Серьогіну, О.Ф. Скакун, О.Д. Тихомирова, Ю.М. Тодику, М.В. Цвіка, О.Н. Ярмиша й інших. Водночас у сучасній правовій доктрині конституційного права питання методологічних засад організації й функціонування органів охорони правопорядку України недостатньо розроблені.

Мета дослідження полягає у визначенні сучасної парадигми дослідження організації й функціонування органів охорони правопорядку України, а по суті, методології дослідження.

Поняття «методологія» походить від грецького слова "methodos", що перекладається як спосіб, шлях дослідження. У сучасній юридичній літературі 
воно сприймається по-різному. Зокрема, М.С. Кельман визначає методологію як учення про структуру, логічну організацію, методи, засоби та форми діяльності дослідника в процесі пізнання ним досліджуваних явиш [2, с. 44].

В.П. Колісник і Ю.Г. Барабаш під час дослідження методології науки конститушійного права вказують на те, шо це вчення про методи пізнання конституційно-правових реалій, теоретичне обгрунтування методів і способів пізнання цих реалій, що використовуються цією наукою $[3$, с. 32].

Колектив авторів підручника з теорії держави і права під керівництвом Ю.А. Ведєрнікова визначає методологію науки теорії держави і права як систему принципів, підходів та методів пізнання державно-правових явиш, зокрема закономірностей виникнення, функціонування й розвитку держави і права, а також учення про шю систему $[4$, с. 21].

Ураховуючи предмет нашого дослідження, найбільш прийнятним уважаємо підхід Д.А. Керимова, який у своїй науковій праці «Методологія права» характеризує досліджуване поняття як загальнонауковий феномен, як інтегральне явище, що поєднуе теоретико-світоглядні концепції, принципи, засоби й методи пізнання (світогляд, філософські методи пізнання та вчення про них, загальні й конкретні наукові методи), які вироблені всіма суспільними науками, у тому числі й комплексом юридичних наук, і застосовуються у процесі пізнання специфіки правової дійсності, іï практичного перетворення [5, с. 46-47].

Методологія дослідження організашіі та функціонування органів охорони правопорядку України є специфічною. Однак ії не можна уявити у відриві від науково обгрунтованих загальнотеоретичних положень, істинність яких перевірена юридичною практикою (у правознавстві основною методологічною наукою вважається загальна теорія держави і права). Грунтуючись на вищенаведеній інтерпретації поняття «методологія права» Д.А. Керимова, нами здійснена спроба запропонувати авторську концепцію методологічних засал дослідження організашіі й функціонування органів охорони правопорядку України.

Усебічне дослідження різноманітних аспектів діяльності органів охорони правопорядку України здійснюється в межах визначених методологічних підходів.

С.Д. Гусарєв та О.Д. Тихомиров методологічний підхід уважають одним із головних компонентів парадигми й розглядають його як «ансамбль», групу взаємозалежних наукових методів. На думку вчених, науковий підхід містить у собі різноманітні взаємозалежні методи, певним чином пов'язані між собою, серел яких один або кілька є головними, а всі інші підпорядковані ї, залежні від них, мають допоміжний характер. Науковці подають хоча й невичерпний, однак достатньо повний перелік таких підходів (історичний, логічний, герменевтичний, порівняльний, ціннісний (аксіологічний), системний, синергетичний, поведінковий (біхевіористський), гуманістичний, кібернетичний, інституціональний, структурний, функціональний, комплексний, системно-функціональний, функціонально-структурний) $[6$, с. 74$]$. 
Схожу думку з приводу категорії, що становить предмет розгляду, обстоює О.Ф. Скакун, яка в юридичній науці виокремлює не тільки комплекс методів, а й загальні (методологічні) підходи та приншипи. Науковець зазначає, шо призначення загальних (методологічних) підходів полягає у визначенні фронтальної стратегії юридичного дослідження, актуалізашії його своїми цілями й завданнями у випадку, коли виявляється недостатність власних методів і виникає необхідність у використанні інших методів філософських, загальнонаукових [7, с. 24].

О.Ф. Скакун уважає, шо методологічного підходу недостатньо для вивчення будь-якого об'єкта, будучи спеціальним, специфічним, він визначається однією категорією, у якій відображена тільки одна (хоча й досить важлива) сторона об'єкта дослідження. Підхід лише намічає ракурс дослідження, задає відповідну програму методологічного забезпечення дослідження (тобто всеб́ічність дослідження вимагає опори на кілька підходів $a \notin m$.$) . Спираючись на позиції інших учених, дослідниця резюмує, що мето-$ дологічні підходи називаються загальними, оскільки визначають «найбільш загальні особливості» тих чи інших методів юридичних досліджень, є формою їнього «зовнішнього вираження» $[7$, с. $24-25]$.

С.Г. Серьогіна під час вивчення форм правління виокремлює гносеологічний, історично-порівняльний та інструментальний або практично-політичний підходи [1, с. 33]. Досліджуючи державний лад України, Л.Р. Наливайко хоча прямо й не вказала обраний нею науковий підхід, однак як методологічну основу дослідження визначила підхід, який спирається на принципи об'єктивності й цілісності $[8$, с. 4].

Не вдаючись у полеміку з приводу інтерпретацій поняття підходу, на нашу думку, тавтологія в назві підходів і методів дослідження не сприяє однозначності ї розуміння, а навпаки, ускладнює цю проблему, що має стати предметом окремого наукового дослідження.

Зважаючи на предмет нашого дослідження, інтегруючим елементом обраної нами методологічної конструкшії $€$ системний підхід. Цей підхід під час опрацювання явиш правової дійсності грунтується на ідеї про те, шо державні та правові явища $\varepsilon$ цілісними сукупностями різноманітних елементів (складових), що взаємодіють між собою і навколишнім середовищем $[6$, с. 76$]$

Екстраполяція системного підходу на визначений нами предмет дослідження дає змогу розглянути органи охорони правопорядку України як шілісні сукупності, шо взаємодіють між собою та іншими державними органами.

Історичний підхід надає можливість з'ясувати особливості становлення й розвитку конституційно-правового регулювання цих органів під впливом історичних, політичних, соціально-економічних, морально-етичних чинників, а також зміну уявлень про їхню роль і функціональне призначення в суспільному житті в різні історичні періоди розвитку державності.

Інструментальний i гуманістичний (людиноцентристський) підходи, що широко застосовуються в науці конституційного права, забезпечують 
дослідження організації й функціонування органів охорони правопорядку 3 погляду забезпечення прав і свободд людини, ефективності здійснення цими органами владних повноважень, відносин з іншими державними органами та суб'єктами громадянського суспільства.

Відправним елементом сучасної методології пізнання організашії й функціонування органів охорони правопорядку України варто вважати іï принципи - універсальні, основоположні, загальнозначущі ідеї, що мають найвищу імперативність, якими необхідно керуватися у процесі пізнання предмета дослідження [4, с. 21-22]. До них можна зарахувати принципи об'єктивності, усебічності й повноти, історизму та правового поліцентризму тошо. У зв'язку з цим слушною є думка О.Ф. Скакун, яка зауважила, що принципи, закладені в методах і методологічних підходах, покликані забезпечити концептуальність наукового дослідження своєю неспростовністю $[7$, с. 25$]$.

Принцип об'єктивності з необхідністю вимагає розгляду різних аспектів організації та функціонування органів охорони правопорядку України і їхньої багатогранності, сктадності й суперечливості, ураховуючи сукупність як позитивних, так і негативних моментів, незалежно від суб'єктивного сприйняття й оцінювання.

Наступний принцип - усебічності й повноти - передбачає дослідження організації та функціонування органів охорони правопорядку України, їхніх взаємозв'язків і взаємодії як між собою, так і з іншими державними органами, органами місцевого самоврядування, іншими інститутами громадянського суспільства. Він вимагає акцентувати увагу не тільки на окремих властивостях цих органів, а й не ігнорувати інші чи вважати ï несуттєвими. Умовою отримання достовірних і науково обгрунтованих висновків є. використання якомога більшої кількості критеріїв аналізу діяльності органів охорони правопорядку України. Так, зокрема, не можна пов'язувати їню діяльність тільки із протидією злочинності чи захистом об'єктів права власності, а Јо основних функцій зарахувати тільки виконавчу та охоронну функціі й уважати при цьому основними завданнями тільки суто охорону правопорядку та забезпечення громадської безпеки.

Принцип історизму став теоретичним підгрунтям для дослідження окремих аспектів організації й функціонування органів охорони правопорядку України в різні історичні періоди.

Принцип правового поліцентризму вимагає врахування того, у межах якої правової сім'ї, правової шивілізації досліджуються правові та/чи державні явиша (під правовою шивілізашією варто розуміти групу правових систем, шо мають спільні релігійно-моральні й ідейно-філософські засади, подібні юридичні ознаки та споріднені соціокультурні, нормативно-ціннісні структури й, відповідно, підхід до праворозуміння) [9, с. 45]. У контексті обраного нами предмета достідження це необхідність урахування того, у межах якої правової цивілізації існують органи охорони правопорядку. Для Української держави, яка розбудовується як демократична і правова, продовжується пошук пріоритетів розвитку цих органів. При цьому важ- 
ливим $є$ обрання такої системи цінностей, яка повинна відповідати нашому національному менталітету: або органи охорони правопорядку України розуміються як такі, котрі відстоюють суто інтереси держави (визнання пріоритету держави над людиною), або ж вибір такого шляху розвитку, за якого людина, іiі права та свободи є визначальним фактором їньої діяльності (тобто людиноцентристський підхід).

Центральним компонентом сучасної методології пізнання організації й функціонування органів охорони правопорядку України є метод юридичних досліджень.

Якшо предмет дослідження дає відповідь на питання, які саме проблеми вивчає та чи інша наука, то метод розкриває, як саме, за допомогою яких прийомів і на основі яких принципів відбувається це вивчення $[10$, с. 15.]. Як зазначає О.Ф. Скакун, у загальному розумінні метод - це шлях, спосіб (багато способів (їх множинність)) досягнення постав.теної мети й завдань дослідження; він відповідає на питання: як пізнавати? [7, с. 19].

У сучасних наукових працях, як правило, методологію (поняття, уживане у вузькому розумінні) розглядають як явище, що складається з кількох рівнів, а саме: 1) загальні філософські методи; 2) загальнонаукові методи; 3) конкретно-наукові методи наукового пізнання.

Такий підхід до розуміння структури методології вимагає характеристики трьох вишезазначених видів методів наукового дослідження.

Філософські методи дослідження організації й функціонування органів охорони правопорядку - це система світоглядних ідей і уявлень про місце та роль цих органів у державі й суспі.льстві. Варто погодитись, що кожен із філософських методів має, принаймні, два напрями - діалектичний, що базується на тезі про взаємозв'язок, взаємозалежність і постійний розвиток явиш, і метафізичний, який акцентує увагу на стабільності, самодостатності явиш і їній незмінній сутності [1, с. 37].

Для пізнання органів охорони правопорядку України використовується світоглядний діалектичний метод. Иого використання грунтується на гносеологічних можливостях законів діалектики, а також категорій діалектики. Наприклад, закон єдності й боротьби протилежностей розкриває внутрішнє джерело розвитку системи цих органів. Закон переходу кількості в якість характеризує спосіб еволюції та динаміки процесу розвитку органів охорони правопорядку, спрямовує на пошук закономірностей такого розвитку, визначає кількісні та якісні зміни, шо при цьому відбуваються, розкриває зв'язки між ними. Закон заперечення заперечення надає можливість передбачити напрям розвитку системи цих органів: від простого до складного, від одного - до іншого тошо.

Важливе методологічне значення під час дослідження органів охорони правопорядку України мають категорії діалектики, такі як «форма» і «зміст» (під час дослідження змісту правовідносин за участі цих органів, визначення складових системи органів охорони правопорядку тошо), «явище» $\mathrm{i}$ «сутність» (під час дослідження сутності цих органів та форм ii вияву: функцій органів охорони правопорядку України, правовідносин 
тошо), «система» й «елемент» (під час визначення системи, структури цих органів і виокремлення кожного зі складових цієі системи), «загальне» й «особливе» (при характеристиці загального поняття «правоохоронний орган», «орган охорони правопорядку» й окремо взятих органів охорони правопорядку) тошо.

Застосування діалектичного методу забезпечує з'ясування генези досліджуваних органів, їх постійного розвитку та взаємозв'язку як між собою, так і з іншими державними органами й суб'єктами громадянського суспільства, шо в підсумку дає змогу охарактеризувати їхній сучасний стан, виявити нові тенденції та визначити подальші перспективи розвитку цих органів.

Поряд зі світоглядними філософськими методами визначальну роль у 3'ясуванні тих чи інших сторін організашії й функціонування органів охорони правопорядку України відіграють загальнонаукові методи дослідження. П.М. Рабінович характеризує іх як ключові: саме вони визначають стратегію дослідження, його загальну спрямованість, орієнтують на здобуття, відбір, накопичення визначених у соціально змістовому відношенні фактів і зумовлюють характер і зміст оцінювання отриманих результатів дослідження [11, с. 618-619]. Вони - наступний крок, шо слідує після філософії та передує конкретно-науковим методам, і використовуються в більшості наук.

До таких методів насамперед потрібно зарахувати формально-логічні методи аналізу, синтезу, індукції, дедукції, а також системний, історичний, структурний і функціона.тьний методи.

Зокрема, методи аналізу й синтезу варто сприймати двома частинами одного повного пізнання, у діалектичній єдності. У сфері організації й функціонування органів охорони правопорядку України існує значне коло питань, вирішення яких пов'язано з аналізом і синтезом їньої діяльності. Найбільш рельєфно зазначені методи виявляються під час виокремлення ознак досліджуваних органів, їх класифікашії тошо.

Важливе значення в ході дослілення мала опора на такі логічні методи, як індукція й дедукція. Зокрема, використання дедуктивного методу сприяє визначенню структурно-логічної схеми дослідження, що віддзеркалює шлях пізнання організації й функціонування досліджуваних органів.

Основою методологічної конструкції дослідження конституційно-правових засал організації й функціонування органів охорони правопорядку $\epsilon$ системний метод. В.Л. Федоренко вказує, шо сутність цього методу в юридичній науці полягає в тому, шо досліджуване явише розглядається як певна система, яка включена до системи більш широкого порядку й виконує в ній певні функції, пов'язана з нею різними зв'язками. Науковець визначає цей метод як універсальний інструмент пізнавальної діяльності, незамінний у дослідженні складних динамічних цілісностей [12, с. 137-138].

У межах системного підходу органи охорони правопорядку України розглядаються як елемент державного апарату (поряд з іншими державними органами) і водночас як системне явище із самостійними ознаками, що характеризують їхню інституційно-функціональну організацію. Від якісного 
стану кожної з частин у підсумку залежить стан системи органів охорони правопорядку загалом, завдяки істотним змінам будь-якого органу охорони правопорядку, уся система цих органів набуває нових ознак і якостей.

Історичний метод дає змогу дослідити процеси виникнення, формування й розвитку органів охорони правопорядку України у хронологічній послідовності. На основі аналізу всього фактичного матеріалу були зроблтені загальні висновки, що, отже, базуються на всій сукупності конкретних прикладів, а не на суб'єктивно вибраних, окремих, випадкових фактах.

Структурний метод забезпечує дослідження органів охорони правопорядку як структурно-інституціонального елемента апарату держави, як елемента органів публічної влади.

Використання функціонального методу надало можливість визначити основні напрями піяльності цих органів з огляду на положення чинного законодавства.

Наступна група методів дослідження організації й функціонування органів охорони правопорядку - це конкретно-наукові методи, методи соціально-гуманітарних наук (соціології, статистики, юриспруденції тощо). С.Д. Гусарєв та О.Д. Тихомиров визначають їх як сукупність принципів, прийомів, правил, способів і засобів дослідження конкретних об'єктів [6, с. 88]. Досліджувані нами органи становлять науковий інтерес не тільки для науки конституційного права, а й для інших юридичних і гуманітарних наук. Однак предмет нашого дослідження знаходиться у сфері пізнання юридичної науки, що вимагає опори на використання саме ії спеціальних (специфічних) методів, здебільшого методів, що застосовуються наукою конституційного права.

Техніко-догматичний (формально-догматичний) метод, використаний нами, передбачає дослідження державно-правових явиш у «чистому вигляді», шо існують незалежно від інших видів суспільної та державної діяльності, поза сферою економіки, політики тошо [4, с. 24]. Опора на цей метод сприяє формулюванню дефінішій понять, які становлять предмет дослідження, з'ясуванню справжнього змісту приписів нормативно-правових актів шляхом їх тлумачення. Використання цього методу дає змогу вдосконалювати чинне законодавство про органи охорони правопорядку України та створювати нове, що відповідає потребам суспільства й держави у сфері охорони правопорядку.

Дія науки конституційного права важливе пізнавальне значення має метод порівняльного правознавства (компаративістський метод). Цей метод передбачає зіставлення пізнавальних об'єктів з метою виявлення схожих рис або розходжень між ними $[13$, с. 93]. Він надає можливість урахувати позитивний зарубіжний досвід у питаннях організації та функціонування як усього державного апарату в окремих зарубіжних країнах, так і органів охорони правопорядку як важливої його складової.

Зважаючи на практично-прикладний характер теми наукового дослідження (конституційно-правові засади організації й діяльності органів охорони правопорядку України), а також на його мету, шо полягає в удо- 
сконаленні національного законодавства в означеній сфері правового регулювання, необхідним є використання методу правового моделювання. Моделювання - вивчення об'єкта (оригіналу) шляхом створення та дослідження його копії (моделі), шо заміняє оригінал із певних сторін, які цікавлять суб'єкта пізнання. Використання шього методу дає дослідникові змогу готувати пропозиції щодо вдосконалення національного законодавства, основне функціональне призначення якого полягає в регулюванні й охороні суспільних відносин, тобто фактично стьорювати ідеальну модель поведінки учасників цих відносин $[4$, с. 23-24].

Серед. конкретно-наукових методів С.Д. Гусарєв та О.Д. Тихомиров виокремлюють конкретно-соціологічні методи: збирання правової інформації (опитування, анкетування; аналіз документів; спостереження; вивчення і збирання статистичних јаних) і методи опрацювання отриманої правової інформації $[6$, с. 89]. 3 оглялу на предмет нашого дослідження доцільним $\epsilon$ використання соціологічного методу анкетування, за допомогою якого з'ясовується як суспільна думка, так і думка фахівців у сфері охорони правопорядку з питань організації й функціонування органів охорони правопорядку України.

Отже, методологія дослідження організації й функціонування органів охорони правопорядку України являє собою сукупність підходів, принципів і методів, шо забезпечує отримання достовірних та науково обгрунтованих теоретичних висновків про предмет дослідження, а також формулювання пропозицій щодо вдосконалення правової основи організації й функціонування органів охорони правопорядку України.

\section{Јітература}

1. Серьогіна С.Г. Форма правління: питання конституціӥно-правової теорії та практики : [монографія ] / С.Г. Серьогіна. - Х.: Право, 2011. - 768 с.

2. Кельман М.С. Методологія сучасного правознавства: становлення та основні напрямн розвитку : днс. ... докт. юрнд. наук : спец. 12.00 .01 «Теорія та історія державн і права; історія політичних і правових учень» / М.С. Кельман. - Львів, 2013. - 449 с.

3. Конституційне право України : [підруч. для студ. виш навч. закл.] / за ред. В.П. Колісника та К.Г. Барабаша. - Х. : Право, 2008. - 416 с.

4. Теорія державн і права : |підручник| / кол. авт.; кер. авт. кол. канд. юрнд. наук, проф. Ю.А. Ведєрніков. - Дніпропетровсык : Дніпроп. держ. ун-т внутр. справ, 2015. - 468 c.

5. Керимов Д.А. Методология права (предмет, функции, проблемы филоссофии права) : Гмонография] / Д.А. Каримов. - 2-е изд. - М. : Аванта+, 2001. - 560 с

6. Гусарев С.Д. Юридична деснтологія / С.Д. Гусарєв, О.Д. Тихомиров. - К. : ВІРА-Р, 1999. $-506 c$

7. Скакун О.Ф. Методы, общне (методологические) подходы н прннципы в юрндических нсследованиях / О.Ф. Скакун / / Методологічні проблеми історико-правових досліджень : матеріали XXIII Міжнародної історито-правової конференції 24-26 вересня 2010 р., Алушта / ред. колегія : І.Б. Усенко (голова), А.Ю Івансва (відп. секр.). Л.П. Гарчева, В.Є. Кириченко. Н.М. Крестовська, Т.В. Музика, Л.М. Подкорнтова, О.М. Редыкіна, Є.В. Ромінський. О.Н. Ярмнш. - К. ; Сімферопо.ль : Доля, 2011. - С. 19-27.

8. Наливайко Л.Р. Державний лад Утраїни: поняття, система, гарантії : автореф. дис. ... докт юрид. наук : спец. 12.00 .01 «Теорія та історія держави і права; історія політичних і правових учень» / Л.Р. Наливайко : Нац. юрид. академія України імені Ярослава Мудрого. X., 2010. - $40 \mathrm{c}$. 
9. Кучул А.М. Правовий поліцентризм як принцип наукового пізнання правових явиш / A.М. Кучук // Науковий вісник Ужгородського національного університету. Серія «Право». - 2013. - Внп. 22. - Ч. І. - Т. 1. - С. 43-46.

10. Загальна теорія державн і права : [підруч. для студ. юрнд. спец. внщ. навч. закл.] / ЦМ.В. Цвік, В.Д. Ткаченко, Л.Л. Богачов та ін.」: за ред. М.В. Цвіка, В.Д. Ткаченко. О.В. Петришина. - Х. : Право, 2002. - 432 с

11. Рабінович П.М. Методологія юридичної науки / П.М. Рабінович / / Юридична енцик.лопедія : в 6 т. / редкол.: Ю.С. Шемшученко (голова редко.л.) та ін. - К. : Укр. енцик.л., 2001. T. 3: K - M. $-2001 .-$ C. $618-619$.

12. Федоренко В.Л. Система конституційного права Улраїни: теоретико-методологічні аспекти : Цмонографія] / В.Л. Федоренко. - К. : Ліра-К, 2009. - 580 с.

13. Терещук M.M. Методологія дослідження форм прав.ління / M.M. Терещук // Теорія та історія держави і права. Серія «Філософія права». - 2009. - № 4. - С. 90-96.

\section{А н о т а ц}

Божљ夫 В. О. Методологія дослідження організації та функціонування органів охорони правопорядку України. - Стаття.

Стаття присвячена визначенню методологічних засад, дослідження організації й функціонування органів охорони правопорядку України. Надається характеристика методологічних підходів, принципів і методів як основних структурних елементів методології дослі-

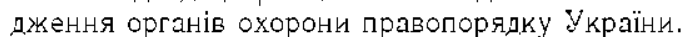

Кльтові слова: методологія дослідження, загальні (методологічні) підходи, принципи, методи.

\section{А н но т а ци я}

Боклк B. A. Методология исследования организации и функционирования органов охраны правопорядка Украины. - Статья.

Статья посвящена определению методологических основ исследования организации и функционирования органов охраны правопорядка Украины. Дана характеристика методологическим подходам, принципам и методам как основным компонентам методологии исследования органов охраны правопорядка Украины.

Kakневиt caова: методология исследования, обшие (методологические) подходи, принципы, методы.

\section{S u ill ill a r y}

Bonyak V. O. Methodology of research of organization and functioning of law enforcement agencies of Ukraine. - Article.

The article deals with definition of methodological principles of research of organization and functioning of law enforcement agencies of Ukraine. The author has described methodological approaches, principles and methods as main structural elements of the research of methodology of law enforcement agencies of Ukraine.

Kety iords: methodology of research, general (methodological) approaches, principles, methods. 